\title{
PREVENTING SPORTS INJURIES IN THE PROCESS OF PHYSICAL FITNESS TRAINING
}

PREVENINDO LESÕES ESPORTIVAS NO PROCESSO DE TREINAMENTO DEAPTIDÃO FÍSICA

PREVINIENDO LESIONES DEPORTIVAS ENEL PROCESO DE ENTRENAMIENTO DE APTITUD FISICA

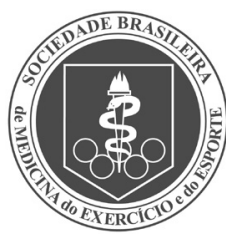

Original Article

ARTIGO ORIGINAL

Artículo Original
Kunxia Su ${ }^{1,2}$

(Physical Education Professional) Lijun Wu $\mathrm{u}^{3}$ (DD

(Physical Education Professional)

Guangtao Zhao ${ }^{3}$ (D)

(Physical Education Professional)

YuJiao Li' (DD

(Physical Education Professional)

1. Department of Sports,

Zhongyuan Institute of Science

and Technology, Zhengzhou,

Henan, China.

2. College of Art and Physical

Education, Gangneung-Wonju

National University, Gangneung,

Korea.

3. Physical Education College,

Henan Finance University,

Zhengzhou, Henan, China.

Correspondence:

Lijun Wu

Zhengzhou, Henan, China. 450046.

sukx888@163.com

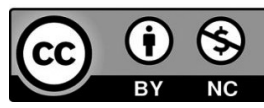

\begin{abstract}
Introduction: It is common for athletes to have accidental injuries in training. Sports injuries damage the health of athletes, dampen their enthusiasm, and affect their normal life and training. Objective: To explore preventive measures against athletes' sports injuries by understanding their sports injuries. Methods: We used the literature data method, a questionnaire, an interview, and mathematical statistics to determine the cause of sports injury accidents of athletes. Results: The locations of sports injuries were fingers, ankle and knee joints, lower back, thighs, etc. Common types of injuries were joint sprains, muscle strains, and soft tissue injuries. Conclusion: Scientific physical training can prevent sports injuries and effectively reduce injuries and accidents caused by sports. Level of evidence II; Therapeutic studies - investigation of treatment results.
\end{abstract}

Keywords: Athletes; Athletic Injuries; Sports.

\section{RESUMO}

Introdução: Não é raro que atletas tenham ferimentos acidentais em seus treinamentos. Lesões esportivas causam danos à saúde dos atletas e reduzem seu entusiasmo, afetando suas vidas normais e seu treino. Objetivo: Explorar medidas preventivas contra lesões esportivas para compreender como tais ferimentos ocorrem. Métodos: Este trabalho utilizou pesquisa bibliográfica, questionário, entrevista, e cálculo estatístico matemático para determinar a causa das lesões esportivas acidentais de atletas. Resultados: As lesões esportivas ocorreram em dedos, articulações de tornozelo e joelho, região lombar, coxas e etc. Tipos comuns de lesão incluíram torção de articulações, estiramento muscular, e feridas em tecidos moles. Conclusão: O treino físico com base científica pode prevenir lesões esportivas e efetivamente reduzir os ferimentos e acidentes causados pelo esporte. Nível de evidência Il; Estudos terapêuticos - investigação de resultados de tratamento.

Descritores: Atletas; Traumatismos em Atletas; Esportes.

\section{RESUMEN}

Introducción: No es raro que los deportistas sufran lesiones accidentales en sus entrenamientos. Lesiones deportivas causan daños a la salud de los atletas y reducen su entusiasmo, afectando sus vidas normales y su entrenamiento. Objetivo: Explorar medidas preventivas contra lesiones deportivas para comprender cómo tales heridas ocurren. Métodos: Este trabajo utilizó investigación bibliográfica, cuestionario, entrevista y cálculo estadístico matemático pata determinar la causa de las lesiones deportivas accidentales de atletas. Resultados: Las lesiones deportivas ocurrieron en los dedos, articulaciones de los tobillos y rodillas, región lumbar, muslos, etc. Entre los tipos de lesiones más comunes se encuentran los esguinces articulares, las distensiones musculares y las heridas en los tejidos blandos. Conclusión: El entrenamiento físico con base científica puede prevenir lesiones deportivas y efectivamente reducir las heridas y accidentes causados por el deporte. Nivel de evidencia Il; Estudios terapéuticos - investigación de resultados de tratamiento.

Descriptores: Atletas; Traumatismo en Atletas; Deportes.

\section{INTRODUCTION}

The article assumes that the research object causes the athlete's sports injury accident. It analyzes the basic concepts, main characteristics, and accident types in sports injury accidents of athletes. ${ }^{1}$ Integrate the model structure of the cause of sports injury accidents for athletes. This can provide a theoretical basis and practical reference for probing the causes of sports injury accidents of athletes and scientifically preventing the occurrence of sports injury accidents of athletes.

\section{METHOD}

\section{Research object}

The article takes the model structure of the cause of sports injury accidents of athletes as the research object.

\section{Research methods}

Literature data method

We searched a total of 61 related documents in the past 20 years with keywords such as athletes, sports injury accidents, and cause model 
structures. We classify and organize documents that are highly relevant to this research. ${ }^{2}$ This provides literature support for the construction of the causal model of sports injury accidents for athletes.

\section{Interview method}

We interviewed athletes, coaches, and team doctors to learn about sports injury accidents during sports training. ${ }^{3}$ We summarized their views and opinions on the causes of athletes'sports injury accidents to construct a model of the causes of athletes' sports injuries.

\section{Questionnaire survey method}

We selected 141 athletes with a history of sports injury accidents and 22 sports-related field experts. ${ }^{4}$ A total of 132 questionnaires were returned to the "Study on the Model Structure of Athletes' Sports Injury Accidents" questionnaires. There are 128 valid questionnaires, the recovery rate is $93.6 \%$, and the effective rate is $97 \%$. There were 21 expert questionnaires and 21 valid questionnaires. The recovery rate was 95.5\%, and the effective rate was $100 \%$.

\section{Mathematical Statistics}

We use Excel and AMOS17.0 software to perform data processing and statistical analysis on the collected and integrated research information. ${ }^{5}$ Then we summarize the survey results and analyze the status quo and development countermeasures.

\section{Analysis algorithm of second-order Bessel fading model of athlete's metabolic function}

Firstly, the shortest aerobic metabolism time, the aerobic metabolism efficiency, and the anaerobic metabolism ratio are used as the model input parameters to construct the three-parameter model input matrix as

$$
A=\left[\begin{array}{lll}
a_{11} & a_{12} & a_{13} \\
a_{21} & a_{22} & a_{23} \\
a_{31} & a_{32} & a_{33}
\end{array}\right]
$$

$a_{11}$ represents the autocorrelation characteristic of the shortest aerobic metabolism time. $a_{22}$ represents the autocorrelation characteristic of aerobic metabolism. $a_{33}$ indicates the autocorrelation characteristic of the anaerobic metabolism ratio. ${ }^{6}$ The autocorrelation characteristics of the model input parameters characterize the stability of the model. Based on the construction of the input parameter matrix, we obtain the second-order Bessel fading model equation as

$$
A D V=\left[\begin{array}{lll}
0.86 & 0.86 / d_{1} & 0.86 / d_{2} \\
1.00 & 1.00 / d_{1} & 1.00 / d_{2} \\
0.95 & 0.95 / d_{1} & 0.95 / d_{2}
\end{array}\right]
$$

$A D V$ represents the characteristic equation of the second-order Bessel fading model. $d_{1}$ represents the correlation distance between the shortest aerobic metabolism time and the effective rate of aerobic metabolism. $d_{2}$ represents the relative distance between the shortest aerobic metabolism time and the ratio of anaerobic metabolism. ${ }^{7}$ The analysis process based on the second-order Bessel fading model is as follows:

$$
\begin{gathered}
A=\left[\begin{array}{lll}
a_{11} & a_{12} & a_{13} \\
a_{21} & a_{22} & a_{23} \\
a_{31} & a_{32} & a_{33}
\end{array}\right], M=\left[\begin{array}{lll}
m_{11} & m_{12} & m_{13} \\
m_{21} & m_{22} & m_{23} \\
m_{31} & m_{32} & m_{33}
\end{array}\right] \\
A D V=\left[\begin{array}{lll}
0.86 & 0.86 / 1.11 & 0.86 / 2.22 \\
1.00 & 1.00 / 1.11 & 1.00 / 2.22 \\
0.95 & 0.95 / 1.11 & 0.95 / 2.22
\end{array}\right]
\end{gathered}
$$

\section{RESULTS}

\section{Definition of related concepts}

Sports injury accidents of athletes: mainly refer to athletes' injuries in sports activities such as physical education, extracurricular sports activities, after-school training, and various sports competitions. ${ }^{8}$

The model structure of the cause of sports injury accidents: The model structure mainly refers to the highly refined and simplified representation of certain things. The model structure of the cause of sports injury accidents is a structured representation of the causes.

\section{Model construction}

\section{Theoretical analysis}

Related accident causation theories can analyze and deduced the causal factors of sports injury accidents. ${ }^{9}$ At present, the most recognized accident cause theory includes "human error theory," "trajectory intersection theory," "management error theory," and "comprehensive theory." "Human error theory" believes that human factors mainly cause errors. The "trajectory intersection theory" believes that errors are caused by the intersection of human and material factors. "Management error theory" believes that the accident occurred because of the unsafe behavior and unsafe conditions of people and things caused by insufficient norms. The "comprehensive theory" believes that accidents are caused by the combined effect of a variety of adverse factors, including social factors. The causal factors of sports injury accidents should include human, physical, management, and social factors. Based on the above factors, the first-order conceptual structure of the causal model of athletes'sports injury accidents is designed. (Figure 1)

\section{Empirical research}

\section{Results of interviews with coaches}

Through the interviews with coaches and the summary and analysis of the content, it is found that teachers believe that the causes of sports injury accidents of athletes are mainly composed of athlete factors and social factors. ${ }^{10}$ Among them, the factors of athletes mainly include three sub-causes: insufficient awareness of safe exercise, poor physical fitness, and poor athletic ability. The social factors mainly include 4 sub-causes that athletes have poor eating habits, heavy schoolwork, a large number of classes, and athletes' parents not paying attention to physical exercises during the growth of athletes.

\section{Results of interviews with team doctors}

After summarizing and analyzing the interviews with 7 team doctors, it is found that the team doctors believe that the causes of sports injury accidents mainly include venue and environmental factors, athlete factors, and social factors. The venue and environmental factors mainly include

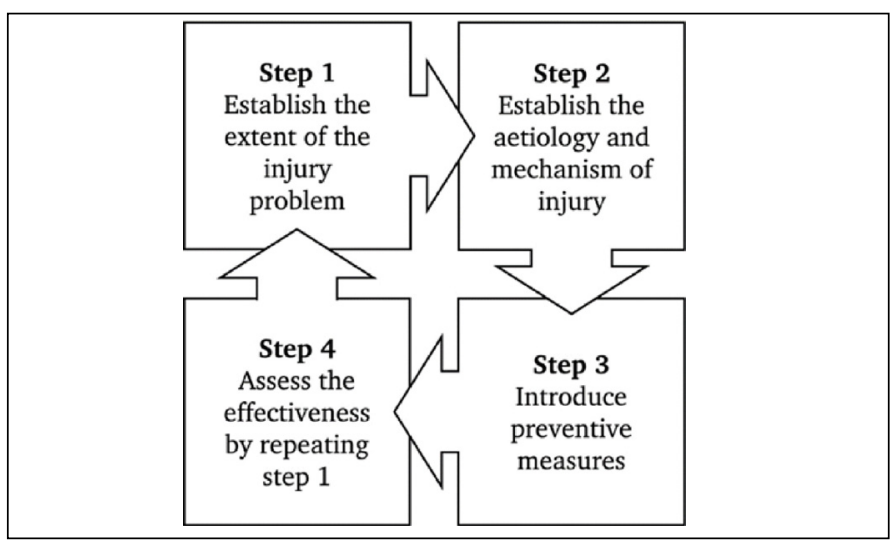

Figure 1. The first-order conceptual structure of the cause of sports injury accidents for athletes. 
two sub-causes, bad weather, and imperfect sports venues. Athlete factors mainly include two sub-causes: weak awareness of safe exercise, poor physical fitness, and disease. The social factors mainly include two sub-causes of the athlete's greater pressure and unscientific diet.

\section{Results of interviews with athletes}

Through interviews with 56 athletes with a history of sports injuries in three institutions, it is found that the athletes believe that their own sports injury accidents are mainly caused by their factors, field factors, and teacher factors. Among them, the factors of athletes mainly include three sub-causes: insufficient awareness of safe exercise, poor physical fitness, and poor athletic ability. Site factors mainly include two sub-causes of the imperfect site and lack of facilities. Teacher factors mainly include two sub-causes: improper teaching organization and a weak sense of responsibility.

\section{Observations of classroom teaching}

Through the observation of the physical education classroom teaching, it is found that there are hidden dangers of sports injury accidents in the four aspects of teachers, sports venues, athletes, and society in the classroom teaching. Teacher factors mainly include three sub-causes: poor sense of responsibility, improper teaching management, and insufficient safety awareness. Venue factors mainly include two sub-causes: insufficient venue, poor lighting, and ventilation in the gymnasium. Athlete factors mainly include three sub-causes: poor preparation activities, poor classroom discipline, and risk-taking behavior.

\section{Preliminary construction of the model}

According to Figure 1 based on the statistics of the related literature on sports injury accidents of athletes in the past 20 years, the model structure of athletes' cause of sports injury accidents is initially constructed. The content includes four first-order causes: people, things, management, and society. Teacher factors, athlete factors, venue facilities, sports environment, human management, material management, national, local, and family 8 second-order causes, and 25 third-order causes such as safe teaching awareness, teaching ability, and physical fitness. (Figure 2)

\section{Verification of the model structure}

\section{Questionnaire verification for athletes and experts}

The causal model constructed tests the objectivity and recognition of the causal factors of athletes' sports injury accidents. We distributed the
"Athlete Sports Injury Accident Causation Model Structure Questionnaire" verification questionnaire to 128 athletes with a history of sports injury accidents and 21 sports-related field experts. The results show that both athletes and experts have a high degree of recognition of most of the causes in the model structure of athletes'sports injury accidents. They did not agree with the structural factors of the two causal models: "teacher inadequate lesson preparation" and "large exercise load."The athlete's recognition rate was $12.3 \%$ and $20.6 \%$, and the expert recognition rate was $19 \%$ and $9.6 \%$, respectively. Therefore, it is excluded from the causal model structure.

\section{Statistical quality verification}

The fitting structure effect is a common method to verify the quality of the structure statistically. Commonly used relevant indicators include $x^{2}, d, p, x^{2} / \mathrm{df}$ (chi-square degree of freedom ratio), NNFI (non-standard fitting index), AGFI (adjusted goodness of fit index), CFI (comparative fitting index), RMSEA (Root Mean Square Approximation Error). /df should be within 0-2. NNFI, AGFI, and CFI are between 0 and 1. The closer it is to 1 , the better. RMSEA close to 0 indicates a good fit. The farther away from 0 , the worse the fit. According to the information obtained in the "Athlete Sports Injury Accident Causation Model Structure Questionnaire," statistical processing was performed. The results are shown in Table 1.

Table 1 shows that the $x^{2} / \mathrm{df}$ value of the primary structure is 1.698 , and the result is between 0 and 5 . The values of NNFI, AGFI, and CFI were $0.936,0.929$, and 0.961 , respectively. The above values are all close to 1 . The RMSEA value is 0.064 , which is in the optimal range of 0.05 to 0.08 . This shows that the fitting effect of the primary structure caused by sports injury accidents of athletes is ideal, and the quality of the structure is

Table 1. The structural quality inspection index of the causal model of athletes'sports injury accidents.

\begin{tabular}{c|c|c}
\hline Structure & Primary structure & Secondary structure \\
\hline$x^{2}$ & 37.362 & 59.218 \\
\hline$d f$ & 21 & 23 \\
\hline$P$ & 0.02 & 0.000 \\
\hline$x^{2} / d f$ & 1.698 & 2.820 \\
\hline $\mathrm{NNFI}$ & 0.936 & 0.935 \\
\hline $\mathrm{AGFI}$ & 0.929 & 0.910 \\
\hline $\mathrm{CFI}$ & 0.961 & 0.859 \\
\hline RMSEA & 0.064 & 0.073
\end{tabular}

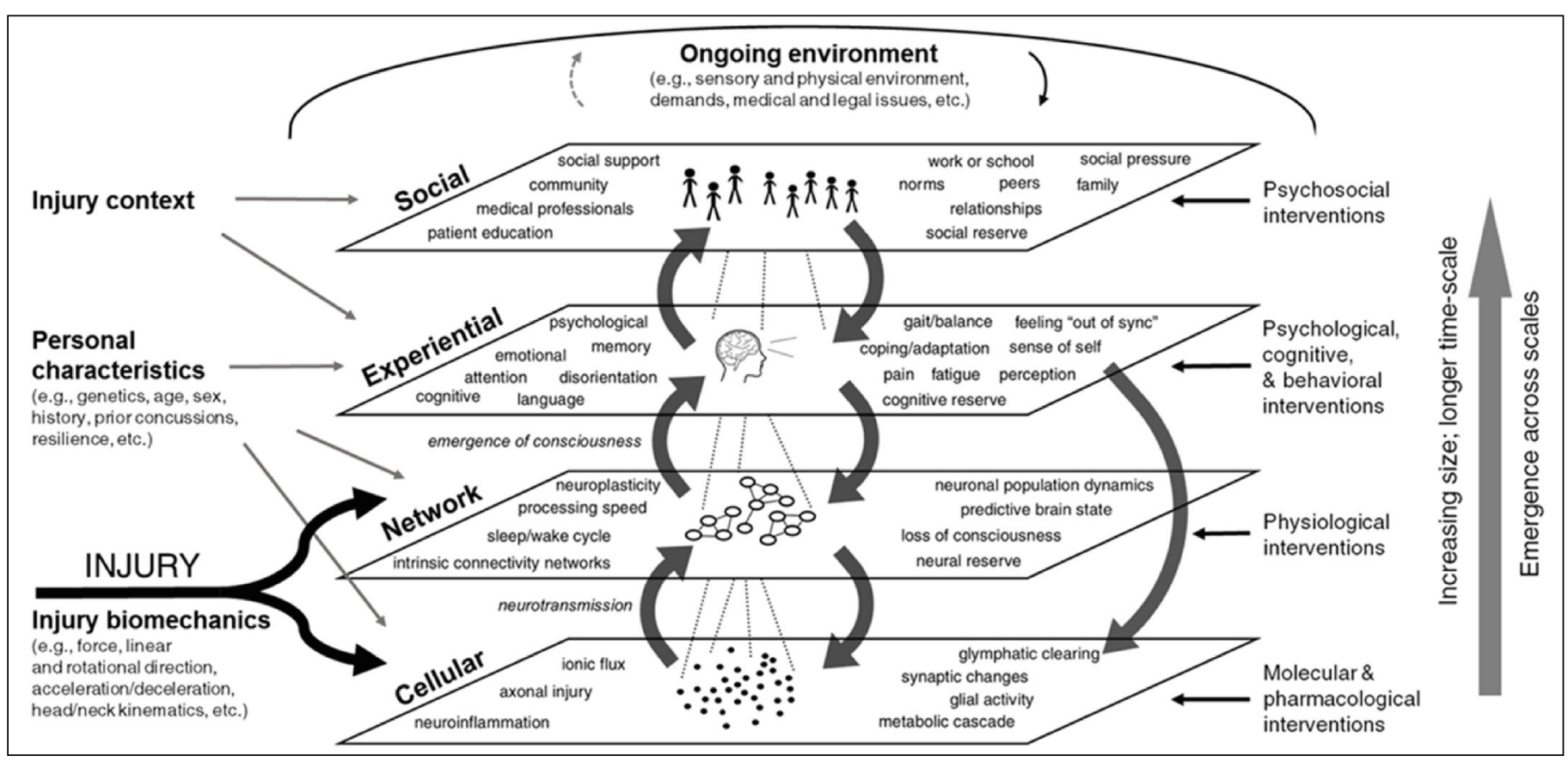

Figure 2. Preliminary construction of the causal model of athletes' sports injury accidents. 
better. The $x^{2} / \mathrm{df}$ value of the secondary structure is 2.820 , which is also between 0-5. The NNFI, AGFI, and CFI values are $0.935,0.910$, and 0.859 , respectively, and they are all close to 1 . The RMSEA value is 0.073 , which is in the optimal range of $0.05-0.08$. This shows that the fitting effect of the secondary structure of the athlete's sports injury accident model is ideal, and the structural quality is better.

\section{DISCUSSION}

According to the verification of athletes and experts, combined with the statistical quality verification of the model structure, the final structure of the athlete's sports injury accident cause model was constructed. (Figure 3)

According to the structure of the causal model, teachers should firmly establish safety awareness and a sense of responsibility and scientifically arrange physical education and training. Athletes should read more information about sports injury accidents to improve their safety awareness. At the same time, athletes should strengthen their physical fitness.
Schools should increase their investment in sports funds and strengthen the improvement of school sports material conditions. Schools, teachers, and parents should actively guide athletes to develop healthy habits. Parents of athletes also need to improve their knowledge of sports safety and provide supervision and advice for athletes' sports safety.

\section{CONCLUSION}

The model structure of athletes' cause of sports injury accidents consists of 4 first-order causes (human, material, management, and social factors) and 8 second-order causes (teacher, athletes, venue facilities, sports environment, human management, and physical management). , National, local, and family), as well as 23 third-level causes including teachers' safety education awareness, teaching ability, and athlete's physical condition.

All authors declare no potential conflict of interest related to this article

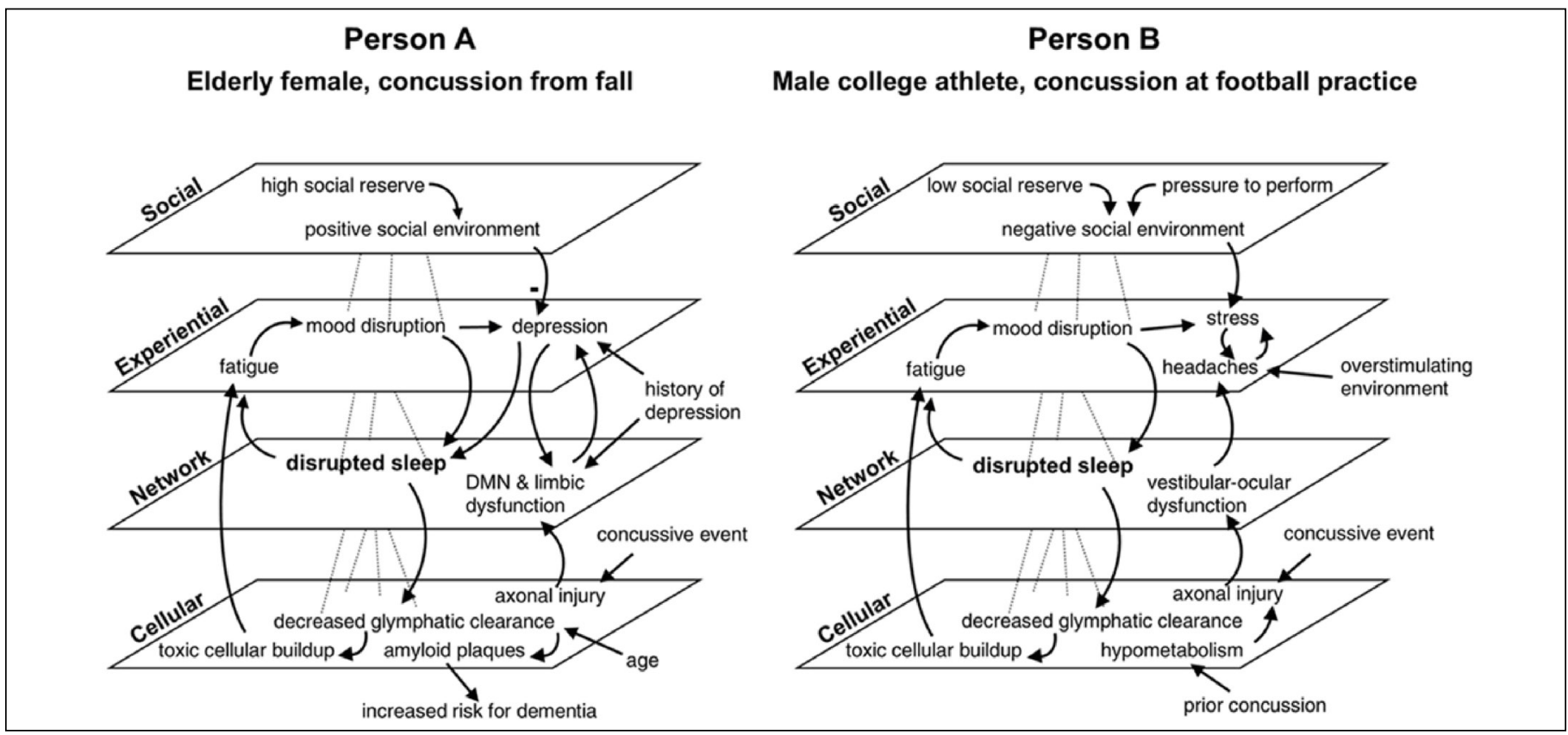

Figure 3. The cause structure of athletes' sports injury accidents.

\section{REFERENCES}

1. Bolling C, Delfino Barboza S, Van Mechelen W, Pasman HR. How elite athletes, coaches, and physiotherapists perceive a sports injury. Translational Sports Medicine. 2019;2(1):17-23.

2. Hulme A, Thompson J, Nielsen RO, Read GJ, Salmon PM. Towards a complex systems approach in sports injury research: simulating running-related injury development with agent-based modelling. British journal of sports medicine. 2019;53(9):560-9.

3. Donaldson A, Callaghan A, Bizzini M, Jowett A, Keyzer P, Nicholson M. A concept mapping approach to identifying the barriers to implementing an evidence-based sports injury prevention programme. Injury prevention. 2019;25(4):244-51.

4. Orchard JW, Meeuwisse W, Derman W, Hägglund M, Soligard T, Schwellnus M et al. Sport medicine diagnostic coding system (SMDCS) and the orchard sports injury and illness classification system (OSIICS): revised 2020 consensus versions. British journal of sports medicine. 2020;54(7):397-401.

5. An KO, Lee KJ. Sports injury prevention and functional training: a literature review. The Asian Journal of Kinesiology. 2021;23(1):46-52.
6. Quartey J, Afidemenyo S, Kwakye SK. Athletes' expectations about physiotherapy in sports injury rehabilitation in greater Accra region. Hong Kong physiotherapy journal. 2019;39(2):101-14.

7. Chandran A, Brown D, Nedimyer AK, Kerr Z. Statistical methods for handling observation clustering in sports injury surveillance. Journal of athletic training. 2019;54(11):1192-6.

8. Chandran A, Morris SN, Wasserman EB, Boltz AJ, Collins CL. Methods of the National Collegiate Athletic Association Injury Surveillance Program, 2014-2015 Through 2018-2019. Journal of athletic training. 2021;56(7):616-21.

9. Bolling C, Barboza SD, Van Mechelen W, Pasman HR. Letting the cat out of the bag: athletes, coaches and physiotherapists share their perspectives on injury prevention in elite sports. British journal of sports medicine. 2020;54(14):871-7.

10. Gokeler A, McKeon PO, Hoch MC. Shaping the Functional Task Environment in Sports Injury Rehabilitation: A Framework to Integrate Perceptual-Cognitive Training in Rehabilitation. Athletic Training \& Sports Health Care. 2020;12(6):283-92. 